\title{
1 Nitric oxide in the physiology and quality of fleshy fruits
}

2 José M. Palma ${ }^{1, *}$, Luciano Freschi ${ }^{2}$, Marta Rodríguez-Ruiz ${ }^{2}$, Salvador González-Gordo ${ }^{1}$,

3 Francisco J. Corpas ${ }^{1}$

$4{ }^{1}$ Group of Antioxidants, Free Radicals and Nitric Oxide y Biotechnology, Food and

5 Agriculture, Estación Experimental del Zaidín, CSIC, Granada, Spain.

$6{ }^{2}$ Laboratório de Fisiologia do Desenvolvimiento Vegetal, Instituto de Biociências, 7 Universidade de São Paulo, São Paulo, Brazil.

8

9 *Corresponding author: José M. Palma (josemanuel.palma@eez.csic.es; Phone: +34 10958 181600)

\section{Highlights}

14 - NO is a relevant regulatory molecule for fruits in chilling injury, disease 15 resistance and ripening.

16 - Exogenous NO provides beneficial effects on fruit quality and seems to mimic 17 endogenous-NO-driven physiological processes.

18 NO action in fruits involves the regulation of antioxidant systems 


\section{Abstract}

21 Fruits are unique to flowering plants and confer a selective advantage as it facilitates

22 seed maturation and dispersal. In fleshy fruits, development and ripening are associated

23 with numerous structural, biochemical and physiological changes, including

24 modifications in the general appearance, texture, flavor and aroma, which ultimately

25 convert immature fruits into a considerably more attractive and palatable structure for

26 seed dispersal animals. Treatment with exogenous nitric oxide (NO) delays fruit

27 ripening, prevents chilling damages, promotes disease resistance and enhances the

28 nutritional value. The ripening process is influenced by NO, which operates

29 antagonistically to ethylene, but it also interacts with other regulatory molecules such as

30 abscisic acid (ABA), auxin, jasmonic acid (JA), salicylic acid (SA), melatonin and

31 hydrogen sulfide $\left(\mathrm{H}_{2} \mathrm{~S}\right)$. NO content progressively declines during fruit ripening, with

32 concomitant increases in protein nitration and nitrosation, two post-translational

33 modifications (PTMs) promoted by reactive nitrogen species (RNS). Dissecting the

34 intimate NO interactions with other ripening-associated players, including reactive

35 oxygen species (ROS), antioxidants, and the aforementioned phytohormones, remains a

36 subject of future challenges. In this context, integrative "omics" and gene editing

37 approaches may provide additional knowledge of the impact of NO in the regulatory

38 processes involved in controlling the physiology and quality traits in both climacteric

39 and non-climacteric fruits.

41 Keywords: antioxidants, chilling, disease resistance, nitric oxide, omics, post42 translational modifications, phytohormones, reactive nitrogen species, reactive oxygen 43 species, ripening. 
Journal of Experimental Botany, Special Issue: Plant NO, 2019

49

50

\section{Introduction}

Since Agriculture was set as a way of living in the Neolithic, the improvement of crops has been one of the leading forces for human population growth. The search for more nutritive products and new farming practices has rendered nowadays the cohabitation of "latest design" and "fashion food" with the necessity of feeding unprecedentedly large population nuclei which are below appropriate nurture conditions. In this framework, fruits from Angiosperms have gained great relevance, and the breeding strategies applied over centuries have allowed increasing productivity and nutritional value of many fruit crop species, placing them as critical sources of vitamins, minerals and other molecules with positive impact in human health (Karasawa and Mohan, 2018).

Botanically speaking, fruits are mature ovaries, which generally undergo intense mitotic activity, growth and differentiation after pollination (Kourmpetli and Drea, 2014; Liu et al., 2015). Under physiological and evolutionary points of view, fruits are structures with an extremely high diversity of shapes, colors, texture, firmness, sizes, density, and chemical composition (within the same plant family, genera or even within varieties of a single species), whose primary role is to maintain and spread the genetic blueprint of the plant species for the next generation, even over significant distances and sometimes with the help of dispersal animals (Karlova et al., 2014; Kumar et al., 2014; Giovannoni et al., 2017; Corpas et al., 2018; Palma et al., 2018a). One of the main peculiarities of most fruits is the ripening process, during which drastic appearance and metabolic changes occur in coincidence with seed maturation. In general terms, the ripening is a highly regulated developmental event that involves reprogramming fruit biochemistry, physiology and gene expression, ultimately leading to changes in coloration, nutritional composition, texture, and palatability. In fleshy fruits, the ripening-associated organoleptic shifts usually rely on chlorophyll degradation plus the synthesis of new pigments (e.g. carotenes, xanthophylls, flavonoids), cell wall softening, accumulation and emission of organic volatile compounds, as well as the synthesis of pectin and proteins, conversion of starch into soluble sugars, together with changes in the total soluble reducing equivalents (Giovannoni, 2004; Goulao and Oliveira, 2008; Barsan et al., 2012; Tohge et al., 2014; Palma et al., 2011, 2018a; Corpas and Palma, 2018; Mukherjee, 2019). Cell architecture is also remodeled during fruit ripening, and in many fleshy fruits the shift in the pigment composition is associated with the conversion of chloroplasts into 
chromoplasts which harbor the newly synthesized carotenoids (Mateos et al., 2003; Palma et al., 2011, 2015; Barsan et al., 2012), although other cell organelles, such as mitochondria and peroxisomes, remain structurally unchanged (Palma et al., 2015). Many of these ripening-associated metabolic rearrangements affect important enzymatic and non-enzymatic antioxidant systems which are involved in maintaining the organ redox status. Those systems include superoxide dismutases (SODs), catalase (CAT), peroxidases (PODs), the enzymes of the ascorbate-glutathione cycle and a set of NADPH-generating dehydrogenases (Mateos et al., 2009; Camejo et al., 2010; Palma et al., 2011, 2015; Huan et al., 2016; Corpas and Palma, 2018; Corpas et al., 2018; Muñoz-Vargas et al., 2018, 2019), ascorbic acid, reduced glutathione and tocopherols (Rodríguez-Ruiz et al. 2018; González-Gordo et al. 2019; Gramegna et al. 2019). Although a moderate redox equilibrium is maintained during the initial phases of fruit ripening, a situation of irreversible oxidative stress takes place during the metabolic and structural dismantlement at ripe and overripe stages (Corpas and Palma, 2018; Corpas et al., 2018).

Fleshy fruits are classically divided as climacteric and non-climacteric depending on their regulatory and metabolic dynamics during the initiation and progression of ripening (Alexander and Grierson 2002). This dichotomy started in the first decades of the twentieth century when a respiratory peak during fruit ripening was observed, linked to the increased emission of the plant hormone ethylene, which was later identified as a driver of the whole process. This classification based on the fruit respiration profile and ethylene dependence at ripening still prevails, grouping tomato, apple, peach, banana, mango, plum, kiwi and papaya, among others within climacteric fruits, whereas pepper, strawberry, orange, bayberry, cucumber and others, are part of the non-climacteric group (Cherian et al., 2014; Liu et al., 2015; Corpas and Palma, 2018). Very recently, after proving that relevant changes occurring during this physiological process were not only associated with the metabolism of reactive oxygen species (ROS) and antioxidants, but also with NO-derived mechanisms (Corpas and Palma, 2018), a nitro-oxidative stress situation was proposed to happen during both climacteric and non-climacteric ripening (Corpas et al., 2018).

These latter works, together with other recent reports implicating $\mathrm{H}_{2} \mathrm{~S}$ and melatonin as part of the mechanisms of NO signaling (Ziogas et al., 2018; Corpas et al., 2019; Mukherjee, 2019), were mainly focused in regulation of ripening initiation and 
progression and paid less attention to other ripening-associated aspects, such as chilling and disease resistance during storage and impacts on fruit organoleptic features. In this present work, an integrative updated view of the involvement of NO and other signaling players in fruit physiology during ripening and under unfavorable conditions, i.e., chilling and pathogen attacks will be given. Due to the influence of these phenomena in the fruit quality, and therefore in their exploitation as economic resources, the impact of these signaling molecules in the quality indexes will also be considered.

\section{Role of NO in chilling injury and disease resistance of fruits}

NO was reported to participate in plant responses against biotic and abiotic stress, as well as in many plant developmental events such as pollen and seed germination, deetiolation, flower setting and development, root organogenesis, nodule metabolism, cell wall lignification, senescence and fruit physiology (Manjunatha et al., 2014; Kumar et al., 2014; Chaki et al., 2015; Melo et al., 2016). Regarding fruits, the pioneer works on NO are attributed to Leshem's group who first demonstrated the involvement of this free radical in the ripening of fruits in an antagonistic way to ethylene (Leshem and Pinchasov, 2000). Since then, much effort has been devoted to investigating the participation of NO in several aspects of the fruit physiology based on data obtained from different crop species and under diverse situations, including drought, chilling, browning, disease resistance and interaction with other signaling molecules, among others (Shi et al., 2011; Kumar et al., 2014; Manjunatha et al., 2014; Bodanapu et al., 2016; Huo et al., 2018; Mukherjee, 2019). Due to the quantitative and qualitative relevance of research conducted on fruits for unraveling the mechanism of action of NO and derived molecules, we will further emphasize this subject here.

Storage at low temperatures is a common practice used to delay senescence of fruits extending their postharvest quality (Chen et al., 2017; Patil et al., 2019), although it is often accompanied by chilling damage as a side effect. One of the most accepted effects promoted by NO in fruits is the mitigation of chilling injuries which is associated with a number of physiological impacts, thus maintaining their metabolism and quality traits for longer. Browning symptoms associated with cold damage were also alleviated by the application of exogenous NO (Peng et al., 2013; Aghdam and Bodbodak, 2014; Barman et al., 2014). The post-harvest treatment with NO after 
storage at low temperature has been reported to reduce the chilling injury of mango peach, melon, orange and others. In Table 1, a summary of the most relevant effects of exogenous NO on the metabolism of ROS and antioxidants in both climacteric and nonclimacteric fruits is provided. Those effects include changes in the activity pattern of SODs, CAT, ascorbate peroxidase (APX), PODs and other enzymes of diverse functions. Alongside with the enzymatic antioxidant system, the total antioxidant activity as well as the content of antioxidant compounds such as ascorbate, glutathione, phenolics, and flavonoids have also been shown to be affected by NO treatment in ripening fruits. Further practices consisting of wrapping pomegranate fruits after NO treatment also prevented those effects (Ranjbari et al., 2018).

This anti-chilling role of NO seems to be leaned on diverse issues which include, among others, an enhancement of the sucrose content (Han et al., 2018) and, chiefly, the antioxidative metabolism (i.e., CAT, SOD, APX, POD) (Wu et al., 2012; Ren et al., 2017; Zhang et al., 2017a; Ghorbani et al., 2018; Liang et al., 2018; Venkatachalam, 2018), although some report found that sodium nitroprusside (SNP), used as a common NO source, behaved in an opposite way with the antioxidant enzymes being depressed (Saba et al., 2017; Tareen et al., 2017) (Table 1). It has been also reported that in the signaling pathway which activates chilling tolerance in cucumber (Cucumis sativus), jasmonic acid (JA) functions upstream of and depend on NO, and this reduces $\mathrm{H}_{2} \mathrm{O}_{2}$ levels due to an enhanced catalase activity and gene expression (Liu et al., 2016). The pre-harvest combined fumigation of peach fruits with NO and the ethylene-synthesis inhibitor aminoethoxyvinylglycine (AVG) generated a higher radical scavenging activity during cold storage and a similar pattern was also observed with the simultaneous application of AVG and salicylic acid (SA), but no consistent trends of the antioxidant enzymes were recorded in those studies (Tareen et al., 2017).

On the other hand, stimulation of nitrogenous compounds such as polyamines, proline and $\gamma$-aminobutyric acid (GABA) has been proved to take place in bamboo and banana fruits subjected to chilling conditions as a consequence of NO pretreatment (Wang et al., 2016; Wang et al., 2017). Additionally, the use of NO and GABA in Cornelian cherry fruits was accompanied by a delayed senescence during post-harvest cold storage concomitant with an enhanced activity of the antioxidant enzymes SOD, CAT, APX and glutathione reductase (GR) (Rabiei et al., 2019). Also $\mathrm{H}_{2} \mathrm{~S}$, which is involved in the regulation of growth and development in plants, has been lately found to 
enhance chilling tolerance by promoting the activity of antioxidant enzymes and increasing the proline and polyphenols contents (Huo et al., 2018; Corpas et al., 2019). Aghdam and Bodbodak (2014) proposed that, among other parameters, the mitigation of chilling in heat-treated fruits was due to the augmentation of the arginine pathways which gives rise to the accumulation of signal molecules like NO, polyamines and proline. In a further study, it has been reported that the use of exogenous melatonin confers chilling tolerance to tomato fruits by promoting polyamine and proline levels as well as the accumulation of NO by triggering the arginine pathway activity (Aghdam et al., 2019).

The beneficial effect of NO in fruit disease resistance against a number of pathogens, basically fungi, has been also demonstrated in diverse species including tomato, pitaya, mango, citrus, peach, kiwi, and others. In Table 2, the impact of NO treatment on plant disease resistance is briefly reviewed as it has been associated to the induction of a series of defense-related genes/enzymes (Zheng et al., 2011a, 2017; Yu et al., 2012; Gu et al., 2014; Hu et al., 2014, 2019; Li et al., 2017). Besides this effect on the defense system, alterations of ROS and antioxidant metabolisms have been reported as a consequence of the exogenous NO application in fruits (Fan et al., 2008; Lai et al., 2011; Zhang et al., 2011, 2017b; Shi et al., 2015; Zhou et al., 2016) (Table 2). The impact of NO in fruit disease resistance resembles the one reported in whole plants (Romero-Puertas and Delledonne, 2016; Mata-Pérez et al., 2016). The cooperative interaction of $\mathrm{NO}$ with other signaling molecules and phytohormones $\left(\mathrm{H}_{2} \mathrm{O}_{2}, \mathrm{JA}, \mathrm{SA}\right)$ have been found to induce disease resistance in diverse fruit species (Fan et al., 2008; Shi et al., 2015; Zheng et al., 2014, 2015).

More research is necessary to fully understand how those and other potential interactions take place, and how they are influenced depending on the crop species and their secondary metabolites which may modulate the specific role of those regulatory molecules, thus contributing to the maintenance of the fruit quality.

The search for new varieties resistant to pest through classical breeding technologies has been a significant focus of attention for plant growers and biotechnological companies. Although still fragmented, the emerging role of NO as an important player in plant response against pathogens can help to identify potential gene targets for transgenic manipulation (e.g., overexpression, silencing via VIGS of RNAi) 
Journal of Experimental Botany, Special Issue: Plant NO, 2019

212 of gene editing approaches (e.g., CRISPR/Cas9). This may allow gaining knowledge for

213 further breeding purposes with quality traits as final objectives and could also help

214 minimizing economical losses due to precocious fruit deterioration during production

215 and transportation. Thus, for example, overexpression of the mitogen-activated protein

216 kinases (MAPKs) could improve the NO-induced disease resistance. In fact, the

217 involvement of MAPKs in the NO-dependent response of tomato fruits against Botrytis

218 cinerea was reported (Zheng et al., 2014, 2015).

NO and fruit ripening. Interaction with phytohormones and regulatory molecules

221

222

223

224

225

226

227

228

229

230

231

232

233

234

235

236

237

238

239

240

241

242

243

As indicated above, early works carried out at the Professor Ya'acov Y. Leshem's laboratory in the Bar-Ilan University opened up a window of opportunity for controlling fruit ripening by demonstrating that NO and ethylene acted antagonistically during this physiological process (Leshem and Pinchasov, 2000). This group reported that exogenously applied NO, either as sodium nitroprusside (SNP), NONO-ate or nitrosoglutathione (GSNO), delayed flower and leaf senescence as well as fruit ripening (Leshem, 2000; Leshem and Pinchasov, 2000). Interestingly, it was found that in kiwifruit ripening was considerably inhibited by $\mathrm{O}_{3}$, and this was reversed by SNP (Tanou et al., 2015). The antagonism between NO and ethylene in climacteric fruits was later corroborated (Prochazkova and Wilhelmova, 2011), and the influence of NO in specific steps of the ethylene biosynthetic pathway has been described (Lindermayr et al., 2006; Cheng et al., 2009). Illustrative examples where NO down-regulates fruit ethylene synthesis include apple (Rudell and Mattheis, 2006), peach (Zhu et al., 2006), strawberry (Zhu and Zhou, 2007), tomato (Eum et al., 2009), among others (Mukherjee, 2019 and references therein).

The ethylene biosynthesis involves two steps (Fig. 1). In the first one, the 1aminocyclopropane-1-carboxylic acid (ACC) synthase (ACS) converts S-adenosylmethionine (SAM) into ACC; whereas in the second step, ACC is oxidized to ethylene by the ACC oxidase (ACO) (Lindermayr et al., 2006; Arc et al., 2013). SAM is continuously replaced through a methionine cycle (Yang cycle) where SAM synthetase (SAMS) adenylates the methionine to render the first precursor of the ethylene synthesis (Freschi, 2013; Rodrigues et al., 2014; Arc et al., 2013). As illustrated in Fig. 1, NO seems to modulate several points of ethylene metabolism, including the reversible 
Journal of Experimental Botany, Special Issue: Plant NO, 2019

244 inactivation of SAMS, also known as methionine adenosyltransferase (MAT), via reversible $S$-nitrosation modification (Lindermayr et al., 2006). Among the three MAT isoforms (MAT1-MAT3) responsible for SAM biosynthesis in Arabidopsis, Lindermayr and colleagues (2006) demonstrated that the $S$-nitrosation of only MAT1 at the Cys-114 position provoked activity inhibition. On the other hand, NO-induced inhibition of both ACS and ACO activity and gene expression has also been described during the ripening of several fleshy fruits (Cheng et al., 2009; Freschi, 2013; Mukherjee, 2019).

Other regulatory partners may participate in the NO-ethylene dialog during fruit ripening. For example, the stress hormone abscisic acid (ABA) has been increasingly demonstrated to maintain crosstalk with both $\mathrm{NO}$ and ethylene, at least during vegetative plant responses such as seed dormancy and germination (Arc et al., 2013; Prakash et al., 2019). Likewise, the application of nitric oxide seems to counteract the ABA-induced senescence in rice (Oryza sativa) leaves (Hung and Kao, 2003), whereas in barley (Hordeum vulgare) NO can retard programmed cell death of aleurone layers (Beligni et al., 2002). Nevertheless, little is known about this interplay among NOethylene-ABA in fruits. Moreover, ethylene and auxin have also been shown to closely interact to modulate ripening-associated processes, including carotenoid biosynthesis in tomato (Su et al., 2015; Cruz et al., 2018). As the auxin-NO signaling interplay also regulates many aspects of plant vegetative development (Freschi et al., 2013), we must remain open-minded to conceive even more complex NO-hormone regulatory networks controlling ripening-related processes in fleshy fruits. Also, the combined pre-treatment of mango fruits with NO and SA modulated the expression of up to six genes involved in the ethylene biosynthesis and the authors proposed that those genes could participate in the NO and SA signaling pathways during ripening (Hong et al., 2014). Additional potential interactions between ethylene metabolism and plant regulatory molecules, including NO, ABA, auxin, JA, SA, gibberellic acid, cytokinins, brassinosteroids, and polyamines during fleshy fruit development and ripening can be found elsewhere (Kumar et al., 2014).

More recently, it has been proposed that the crosstalk between NO and ethylene during the ripening process is mediated by $\mathrm{H}_{2} \mathrm{~S}$ and melatonin (Huo et al., 2018; Mukherjee, 2019; Liu et al., 2019). In this interaction, NO participates through its action over the ethylene biosynthesis, but it also promotes post-translational modifications of 
may in turn lead to changes in cell wall firmness, pericarp browning, anthocyanin, and flavonoid biosynthesis as well as in the profiles of ROS/RNS, lipid peroxidation and chlorophyll degradation, aspects which are associated to the delayed ripening promoted by those two regulatory molecules, $\mathrm{NO}$ and $\mathrm{H}_{2} \mathrm{~S}$. In this scenario, melatonin seems to interact with NO influencing the activity of diverse antioxidant enzymes, ultimately leading to similar symptoms to those displayed by $\mathrm{NO}$ and $\mathrm{H}_{2} \mathrm{~S}$ (Mukherjee, 2019). In fact, melatonin has been proved to delay postharvest senescence of pear fruits by triggering the NO-mediated inhibition of the ethylene synthesis genes. Consequently, melatonin seems to act upstream of NO in plant systems (Liu et al., 2019). Moreover, during sweet pepper fruit ripening, $\mathrm{H}_{2} \mathrm{~S}$ production capacity has been reported to increase as a consequence of a higher L-cysteine desulfhydrase activity. In this system, $\mathrm{H}_{2} \mathrm{~S}$ inhibits the activity of the NADPH-generating isocitrate dehydrogenase (NADPICDH) possibly by a persulfhydration process, what indicates that $\mathrm{H}_{2} \mathrm{~S}$ may regulate the NADPH production during fruit ripening in a coordinated way with NO (Muñoz-Vargas et al., 2018, 2019).

Given the relevant and very well-established role of ethylene on climacteric ripening, fruit crops belonging to this group, including the genetic model tomato, may represent more promising systems to dissect the mechanisms behind the NO-ethylene interaction than non-climacteric fruits. But, comparative studies on the NO action on both climacteric and non-climacteric fruits should also occupy a prominent place in future years of NO and fruit biology research.

Accumulating evidence indicates that, regardless of belonging to the climacteric or non-climacteric groups, fleshy fruits display some common physiological and metabolic responses to exogenous NO treatment. By comparing the effects triggered by the NO treatment on several crop fruit species (Table 1), it becomes clear that NO frequently prolongs fruit post-harvest lifespan and sometimes provides added nutritional value to them, and both these effects have obvious commercial and human health implications (Manjunatha et al., 2014; Corpas and Palma, 2018; Corpas et al., 2018; Steelheart et al., 2019). Additionally, as indicated above, the treatment of diverse fruits with NO triggers other symptoms of economic/commercial relevance such as preventing browning in apple, lowering chilling injury in banana, increasing firmness in blueberry and bayberry, softening delay in papaya, mango and strawberry, and inducing disease resistance during postharvest storage, among others (Table 1). Accordingly, 
treatment with NO promotes, at least, the maintenance of organoleptic properties and their nutritional value.

Very recently, transcriptomic and proteomic approaches have started to reveal how NO may affect the intimate metabolism of sweet pepper during ripening. The analysis of differentially expressed genes (DEGs) by RNA-Seq showed that about 2,200 genes were up-regulated and around 3,300 were down-regulated in the transition from immature green fruits to ripe red ones (Corpas et al., 2018). However, the treatment of fruits with 5 ppm NO lowered the number of down-regulated genes (above 1,600), but 2,125 were up-regulated (González-Gordo et al., 2019). This indicates that NO, either directly or indirectly, leads to extensive changes in gene expression during fruit ripening. Moreover, proteomic analysis by iTRAQ rendered that, from the 2,574 identified proteins in pepper fruits, about 692 and 497 were differentially overrepresented in green and red ripe fruits, respectively. After NO treatment, only 24 proteins were more abundant in green pepper while 55 displayed lower levels (Palma et $a l ., 2018 \mathrm{~b})$. Although transcriptomic and proteomic data are always difficult to match and to infer from one to another, it seems plausible to assume that besides influencing the global transcript abundance NO may also play a significant role on the translational control of protein accumulation in ripening fruits. However, more research is necessary to validate this hypothesis.

\section{Endogenous $v s$. exogenously added NO}

Several aspects need to be taken into consideration when comparing data from the experiments based on NO treatments referred above: (a) those experiments were carried out with exogenously-added NO levels which usually overpass those operating under physiological conditions; (b) the route followed by the NO molecules after its application is difficult to be experimentally investigated, and, at present, the fraction of the applied NO that actually gain access to the target cells inside large fruits is far from being determined; (c) the average halflife of $\mathrm{NO}$ in aqueous solution is about 10 seconds, but this value can be totally different within fruit cells, where osmolytes, sugars, diverse antioxidants and compounds (secondary metabolites) specific for each fruit species can interfere with the NO stability and action; (d) the effects observed after NO treatment are usually detectable after some days, so some still uncharacterized 
Journal of Experimental Botany, Special Issue: Plant NO, 2019

342 on/off switch seems to be activated by the gas; (e) once inside the cell, NO can either 343 give rise to a series of RNS promoting PTMs of some proteins ( $S$-nitrosation, nitration 344 or nitro-alkylation) and lipid nitration or interact with ROS. So that, in the current state 345 of the art, as depicted in Figs. 2A, 2B, two plausible ways of investigating the role of 346 NO in fruit ripening can be highlighted: 1) by treatment with exogenous NO, as it has 347 been thoroughly reported here, and considering the cues (a) to (e) referred above; and 2) 348 by promoting the production of endogenous NO. Regarding this latter issue, Bonadapu 349 et al (2016) found that the short root (shr) tomato mutant displayed overproduction of $350 \mathrm{NO}$ and this gave rise to suppression of fruit growth and ripening. Alternatively, the 351 level of endogenous NO can be enhanced by several pre-harvest treatments. Thus, treatment with L-arginine alone and combined with methyl salicylate was positively correlated with endogenous NO concentration in tomato, and this promoted the fruit resistance to Botrytis cinerea (Zheng et al., 2011b; Zhang et al., 2017). Furthermore, the treatment of tomato fruits with the elicitor from B. cinerea led to a rapid biosynthesis of NO and also activated the defense enzyme system (Zheng et al., 2011a). Likewise, the application of the yeast saccharide from Penicillium expansum triggered a marked increase of endogenous NO in peach fruits, and this reduced decay during postharvest storage (Yu et al., 2012). In apple, it was reported that the metabolism of endogenous NO during growth and development of fruits influenced the internal profiles of nitrosothiols (SNOs), L-arginine, and nitrite and nitrate contents (Zhang et al., 2011).

From the metabolic and physiological points of view, the beneficial effects of $\mathrm{NO}$, either from exogenous or endogenous sources, during the ripening process are also related with the ROS metabolism and antioxidants, thus weaving a multifaceted chain of reactions which remains to be better characterized in the context of fruit biology. For example, it has been demonstrated that treatment with $5 \mathrm{ppm}$ NO provokes an increase of about $40 \%$ in the ascorbate content of sweet pepper fruits (Rodríguez-Ruiz et al., 2017a), thereby incrementing the fruit nutritional content. Additional reports on the interactions among RNS and ROS in fruits will be addressed below.

\section{Fruit ripening, RNS and ROS}

372 Like most other plant organs, fruits are able to generate NO, although there is still no 373 unequivocal data on the specific sources, either enzymatic or non-enzymatic, as it still 
Journal of Experimental Botany, Special Issue: Plant NO, 2019

374 prevails in higher plants where diverse sources have been proposed (Astier et al., 2018;

375 Steelheart et al., 2019). However, what has been demonstrated via different detection 376 approaches is that NO level decreases during fruit ripening (Chaki et al., 2015; Muñoz-

377 Vargas et al., 2018). Concomitantly, increased amounts of both protein nitration and 378 SNOs are detected as fruits ripen (Chaki et al., 2015; Rodríguez-Ruiz et al., 2017b; 379 Corpas and Palma, 2018; Corpas et al., 2018). Protein nitration is considered thus far an 380 irreversible PTM in plants which occurs by the covalent addition of a nitro $\left(-\mathrm{NO}_{2}\right)$ 381 group to specific tyrosines in the polypeptide chain, and it is mediated by the formation 382 of peroxynitrite $\left(\mathrm{ONOO}^{-}\right)$as a consequence of the reaction between superoxide radicals $383\left(\mathrm{O}_{2}{ }^{--}\right)$and NO (Lozano-Juste et al., 2011; Corpas et al., 2013; Chaki et al., 2015). On of a NO group to the thiol (-SH) side chain of cysteine present in peptides or proteins giving rise to a family of NO-derived molecules called protein SNOs (Astier et al., 2011). Both PTMs can modify protein functions, either positively favoring their activity or negatively by interacting with specific aminoacids and turning them missfunctional.

According to the respective profiles of NO, protein nitration, and $S$-nitrosation, it could be hypothesized that as ripening progresses the NO present at a high level in unripe fruits is driven to promote both PTMs, so NO is consumed in the process, thereby explaining the lower concentrations found in ripe fruits (Fig. 2C). Nitration of fatty acids has also been reported to occur in plant tissues and, in fact, the presence of nitro-fatty acids $\left(\mathrm{NO}_{2}\right.$-FAs) has been proved in extra virgin olive oil (EVOO) (MataPérez et al., 2017). $\mathrm{NO}_{2}$-FA can bind, via a Michael addition, to a thiol group of proteins through nitro-alkylation which could be part of a signaling process (SánchezCalvo et al., 2013; Mata-Pérez et al., 2017) such as it has been reported in animal cells (Geisler and Rudolph, 2012). Although this nitro-alkylation event has not been investigated during the ripening of olive fruits, it seems tempting to speculate that such reaction may play a role in fine-tuning the regulatory mechanisms behind the drastic metabolic changes triggered by ripening in fleshy fruits. Whether or not the NO applied to fruits follows the pattern shown in Fig. 2C remains to be investigated, and this would allow addressing most of the cues (a) to (e) indicated above. For example, when sweet pepper was exposed to exogenous $\mathrm{NO}$, the ripening process was delayed several days, and the pattern of nitrated proteins was influenced by such treatment. The profile of nitrated proteins in pepper fruits treated with $5 \mathrm{ppm}$ NO, which is an extremely high 
concentration comparing to internal $\mathrm{NO}$ levels, resembled that of immature green fruits rather than that of ripe red fruits (Chaki et al., 2015). Initially, these findings may seem somehow contradictory, as the higher NO availability would imply a higher formation of $\mathrm{ONOO}^{-}$which could favor protein nitration. This might be true if the generation rate of superoxide radicals is also enhanced since the reaction between $\mathrm{NO}$ and $\mathrm{O}_{2}{ }^{--}$is equimolar, so the level of $\mathrm{O}_{2}{ }^{-}$is possibly limiting the $\mathrm{ONOO}^{-}$production.

Interestingly, five-fold increased activity of the Rboh has been reported in sweet pepper after fruits ripened (Chu-Puga et al., 2019). Rboh, corresponds to a respiratory burst oxidative homologue, a protein found in plants that shares functional similarity to the animal NADPH oxidase, and is involved in the generation of $\mathrm{O}_{2}{ }^{--}$(Suzuki et al., 2011; Zhang et al., 2018). However, once again, the $\mathrm{O}_{2}{ }^{--}$concentration at which this species is generated intracellularly might never be in the same range as the $5 \mathrm{ppm}$ NO applied to fruits. So, this behaviour observed in the profile of protein nitration leads us to think that only a little part of the NO molecules administered to the fruits gained access to the target cells inside this organ where they were integrated in the RNS metabolism and operated through diverse mechanisms, including nitration and $S$ nitrosation of proteins, and perhaps also by nitro-alkylation of fatty acids. The combination of NO with reduced glutathione (GSH) to form GSNO, and the subsequent removal of this molecule via GSNO reductase (GSNOR) activity is also a possibility that deserves further investigation. However, GSNOR activity has been shown to decline during pepper fruit ripening (Rodríguez-Ruiz et al., 2017b), thereby potentially limiting the tissue capacity to reduce the cellular levels of this NO reservoir as ripening progresses.

Considering that protein nitration in plants has been associated with biotic and abiotic stress, and that both unfavorable conditions develop oxidative stress symptoms, this PTM has been used traditionally as an oxidative stress marker (Corpas et al., 2009, 2013; Chaki et al., 2015). Moreover, enhanced lipid peroxidation takes place during fruit ripening (Corpas et al., 2018; Chu-Puga et al., 2019), thus indicating that a moderate situation of oxidative stress is linked to fruit ripening. This combination of increased oxidative and RNS metabolisms allowed concluding that nitro-oxidative stress undergoes at ripening. However, due to the physiological meaning of the ripening for the survival of plant species throughout generations, the term "phystress" is 
Journal of Experimental Botany, Special Issue: Plant NO, 2019

439 proposed in this review to refer to the sort of physiological stress that takes place in 440 ripening fruits.

Under natural conditions, it has been found that catalase, an enzyme that 442 catalyzes the disproportionation of $\mathrm{H}_{2} \mathrm{O}_{2}$ into $\mathrm{H}_{2} \mathrm{O}$ and $\mathrm{O}_{2}$, is the major protein nitrated 443 during the ripening of pepper fruits (Chaki et al., 2015). This PTM is responsible for the 444 lower catalase enzyme activity determined in ripe fruits (Mateos et al., 2003; Chaki et 445 al., 2015). Another protein involved in controlling cellular $\mathrm{H}_{2} \mathrm{O}_{2}$ levels is the 446 chloroplastic peroxiredoxin II E (Prx-IIE). In preliminary studies, also developed in 447 sweet pepper, it was reported that Prx-IIE was potentially $S$-nitrosated during the 448 ripening process, although thus far it is not precisely known if this modification results 449 either in gain or loss of function (Rodríguez-Ruiz et al., 2017b). This connection 450 between catalase and Prx-IIE is an interesting point since $\mathrm{NO}$ and $\mathrm{H}_{2} \mathrm{O}_{2}$ are among the 451 most representative species from the RNS and ROS families, respectively, and are 452 increasingly implicated in cell signaling events (Camejo et al., 2010; Airaki et al., 2015; 453 Huan et al., 2016; Jiménez-Quesada et al., 2017; Corpas et al., 2018; Palma et al., 2019; 454 Steelheart et al., 2019).

The cause (NO) and consequence (ROS and antioxidants) relationship has been 456 more widely investigated in cases where NO has been exogenously added in different 457 forms (Table 1). One of the most remarkable examples of this relationship was reported 458 in the non-climacteric sweet pepper. In this fruit, the treatment with NO allowed 459 increasing up to $40 \%$ in ascorbate content, which was associated with higher gene 460 expression and enzyme activity levels of the galactono- $\gamma$-lactone dehydrogenase, the 461 enzyme responsible for catalyzing the last step of the ascorbate biosynthesis in plants 462 through the L-galactose pathway (Rodríguez-Ruiz et al., 2017a). However, the effect of 463 NO treatment in the ROS and antioxidant metabolism may be extended to other 464 parameters, although it must be said that the available information on the intimate 465 mechanisms behind such relationships is still unknown. In tomato, for instance, 466 although a number of papers establishes a clear interaction among NO, ROS and other 467 signaling molecules (primarily hormones) in different vegetative tissues (Gémes et al., 468 2011; Poór et al., 2015; Piterkova et al., 2013; Corpas et al., 2018), such signaling 469 interplays have not been determined in the fruit tissues yet. Again, the use of new 470 "omic" and gene editing technologies can be very useful to understand those processes 471 as the combination of genetic engineering of NO, ROS and hormone metabolisms 
Journal of Experimental Botany, Special Issue: Plant NO, 2019

472 followed by detailed screening of the impacts of such manipulations on fruit 473 transcriptome, proteome and metabolomic profiles may provide particularly 474 comprehensive information about NO-ROS-hormone interplay during the fruit 475 development and ripening.

\section{Appraisal and future perspectives}

478 Independently on whether fruits are climacteric or non-climacteric, NO has been 479 demonstrated to delay ripening and to affect their redox dynamics by improving their 480 antioxidant activity and, therefore, favoring their nutritional value. The limited data 481 currently available on RNS and ROS metabolisms of pepper fruits under natural 482 conditions (Chaki et al., 2015; Mateos et al., 2009; Rodríguez-Ruiz et al., 2017b; 483 Corpas and Palma, 2018) indicate that the NO added exogenously to fruits develops the 484 same symptoms that perhaps occur physiologically during ripening. Therefore, it is 485 plausible that the approach of exposing fruits to unusual concentrations of $\mathrm{NO}$, 486 commonly above physiological levels, may be useful to mimic the internal conditions of this organ. Nevertheless, this has to be investigated in more detail given the diversity of agronomically-relevant fruits and their significant differences in molecular composition.

489 Thus, a considerable variation in the content of sugars, organic acids, antioxidants, 490 lipids, vitamins, polyphenols, fibers, alkaloids and others might determine the final 491 response of fruits to the NO treatment. Conducting the approaches reported above on 492 the stimulation of the endogenous NO sources by treatment with eliciting molecules on 493 fruit ripening mutants, or, for example, silencing genes which may provoke imbalances 494 in the ROS/RNS metabolism (SOD,CAT, GSNOR), can also provide irrefutable data which allows depicting the scenario at each development and ripening stages.

The interaction between NO and the endogenous antioxidants, as revealed in this review, portrays an exciting perspective, since it allows drawing, together with the ROS metabolism, a theoretical and balanced picture which could be disturbed under stress conditions, and also by the presence of other key molecules such as phytohormones, $500 \mathrm{H}_{2} \mathrm{~S}$ and melatonin, as it has been reported very recently (Muñoz-Vargas et al., 2018; 501 Mukherjee, 2019; Liu et al., 2019). In pepper fruits, which are one of the richest plant 502 sources of ascorbate, the interaction between this soluble antioxidant and the 503 exogenously added NO, and other RNS-derived PTMs such as S-nitrosation and 
nitration, offers an exciting target for future investigations. In fact, ascorbate has been proposed to function as a redox buffer which modulates the fruit ripening process in pepper (Palma et al., 2015).

On the other hand, the focus of the research on the NO impact on fruit physiology can be significantly diversified depending on the final objectives. From a scientific and academic point of view, the strategy of applying NO to fruits, as performed so far by different groups is, to our concern, adequate since it enables us to gain knowledge on this regulatory facet of the ripening process, and it can also provide virtual scenarios which could be near the in vivo situation. Nevertheless, if the interest comes from agronomical and economic viewpoints, where a significant goal may be to facilitate postharvest storage and improve fruit nutritional values via NO treatment, it must be taken into consideration that subjecting tons of fruits with gaseous NO is not a feasible practice. Then, new alternatives need to be developed, including either the discovery of natural NO sources which can be cheap and easily handled or the use of NO production elicitors.

Clarifying how these NO-triggered events mechanistically influence fruit physiology and metabolism will inexorably require the use of a wide variety of methodological approaches and strategies, some of which are currently available and others yet to be developed. Modern approaches based on "omics" tools have the potential to help to elucidate many of the open questions in this subject. Very recently, a study of the effect of $\mathrm{NO}$ in the transcriptome of sweet pepper fruits has been accomplished, and a set of genes displaying differential expression due to the NO treatment has been reported. Some of them are related to chloroplast metabolism, lipid metabolism, cysteine metabolism, response to $\mathrm{H}_{2} \mathrm{O}_{2}$, and regulation of $\mathrm{NO}$ metabolic processes (González-Gordo et al., 2019). Integrating transcriptomics, proteomics and metabolomics in this field will, perhaps, be part of the solution, and, of course, using the large datasets generated via these approaches to identify the mechanisms behind NO action in fruits represents an imminent challenge for both $\mathrm{NO}$ and fruit biologists. 
Journal of Experimental Botany, Special Issue: Plant NO, 2019

\section{Acknowledgments}

536 Financing by ERDF funds through the Ministry of Economy and Competitiveness 537 (AGL2015-65104-P) and by Junta de Andalucía (group BIO192), Spain, is 538 acknowledged. The work of LF is supported by Fundação de Amparo à Pesquisa do 539 Estado de São Paulo (FAPESP, grant nos \#2016/01128-99 and \#2018/16389-8).

540 


\section{References}

Aghdam MS, Bodbodak S. 2014. Postharvest heat treatment for mitigation of chilling injury in fruits and vegetables. Food and Bioprocess Technology 7, 37-53.

Aghdam MS, Luo Z, Jannatizadeh A, Sheikh-Assadi M, Sharafi Y, Farmani B, Fard JR, Razavi F. 2019. Employing exogenous melatonin applying confers chilling tolerance in tomato fruits by upregulating ZAT2/6/12 giving rise to promoting endogenous polyamines, proline, and nitric oxide accumulation by triggering arginine pathway activity. Food Chemistry 275, 549-556.

Airaki M, Sánchez-Calvo B, Leterrier M, Valderrama R, Chaki M, BegaraMorales JC, Barroso JB, del Río LA, Palma JM, Corpas FJ. 2015. Spatial and temporal regulation of the metabolism of reactive oxygen and nitrogen species during the early development of pepper (Capsicum annuum L.) seedlings. Annals of Botany 116, 679-693.

Alexander L, Grierson D. 2002. Ethylene biosynthesis and action in tomato: a model for climacteric fruit ripening. Journal of Experimental Botany 53, 2039-2055.

Arc E, Sechet J, Corbineau F, Rajjou L, Marion-Poll A. 2013. ABA crosstalk with ethylene and nitric oxide in seed dormancy and germination. Frontiers in Plant Science 4, 63 .

Astier J, Gross I, Durner J. 2018. Nitric oxide production in plants: an update. Journal of Experimental Botany 69, 3401-3411.

Astier J, Rasul S, Koen E, Manzoor H, Besson-Bard A, Lamotte O, Jeandroz S, Durner J, Lindermayr C, Wendehenne D. 2011. S-nitrosylation: an emerging posttranslational protein modification in plants. Plant Science 181, 527-533.

Barman K, Asrey R, Pal RK, Jha SK, Bhatia K. 2014. Postharvest nitric oxide treatment reduces chilling injury and enhances the shelf-life of mango (Mangifera indica L.) fruit during low-temperature storage. Journal of Horticultural Science \& Biotechnology 89, 253-260.

Barsan C, Zouine M, Maza E, Bian W, Egea I, Rossignol M, Bouyssie D, Pichereaux C, Purgatto E, Bouzayen M, Latché A, J-C Pech. 2012. Proteomic analysis of chloroplast to chromoplast transition in tomato reveals metabolic shifts coupled with disrupted thylakoid biogenesis machinery and elevated energy-production components. Plant Physiology 160, 708-725.

Beligni MV, Fath A, Bethke PC, Lamattina L, Jones RL. 2002. Nitric oxide acts as an antioxidant and delays programmed cell death in barley aleurone layers. Plant Physiology 129, 1642-1650.

Bodanapu R, Gupta SK, Basha PO, Sakthivel K, Sadhana, Sreelakshmi Y, Sharma R. 2016. Nitric oxide overproduction in tomato $s h r$ mutant shifts metabolic profiles and suppresses fruit growth and ripening. Frontiers in Plant Science 7, 1714. 
Camejo D, Martí MC, Román P, Ortiz A, Jiménez A. 2010. Antioxidant system and protein pattern in peach fruits at two maturation stages. Journal of Agricultural and Food Chemistry 58, 11140-11147.

Chaki M, Álvarez de Morales P, Ruiz C, Begara-Morales JC, Barroso JB, Corpas FJ, Palma JM. 2015. Ripening of pepper (Capsicum annuum) fruit is characterized by an enhancement of protein tyrosine nitration. Annals of Botany 116, 637-647.

Cheng G, Yang E, Lu W, Jia Y, Jinag Y, Duan X. 2009. Effect of nitric oxide on ethylene synthesis and softening of banana fruit slice during ripening. Journal of Agricultural and Food Chemistry 57, 5799-5804.

Chen J, Liu X, Li F, Li Y, Yuan D. 2017. Cold shock treatment extends shelf life of naturally ripened or ethylene-ripened avocado fruits. PLoS One. 2, e0189991.

Cherian S, Figueroa CR, Nair H. 2014. 'Movers and shakers' in the regulation of fruit ripening: a cross-dissection of climacteric versus non-climacteric fruit. Journal Experimental Botany 65, 4705-4722.

Chu-Puga A, González-Gordo S, Rodríguez-Ruiz M, Palma JM, Corpas FJ. 2019. NADPH oxidase (Rboh) activity is up regulated during sweet pepper (Capsicum annиит L.) fruit ripening. Antioxidants 8, 9.

Corpas FJ, Chaki M, Leterrier M, Barroso JB. 2009. Protein tyrosine nitration: a new challenge in plants. Plant Signaling and Behaviour 4, 920-923.

Corpas FJ, Palma JM, del Río LA, Barroso JB. 2013. Protein tyrosine nitration in higher plants grown under natural and stress conditions. Frontiers in Plant Science 4, 29.

Corpas FJ, Palma JM. 2018. NO on/off in fruit ripening. Plant Biology 20, 805-807.

Corpas FJ, Freschi L, Rodríguez-Ruiz M, Mioto PT, González-Gordo S, Palma JM. 2018. Nitro-oxidative metabolism during fruit ripening. Journal of Experimental Botany 69, 3449-3463.

Corpas FJ, González-Gordo S, Cañas A, Palma JM. 2019. Nitric oxide (NO) and hydrogen sulfide $\left(\mathrm{H}_{2} \mathrm{~S}\right)$ in plants: Which comes first? Journal Experimental Botany, doi: 10.1093/jxb/erz031

Cruz AB, Bianchetti1 RE, Rodrigues Alves FR, Purgatto E, Pereira Peres LE, Rossi M, Freschi L. 2018. Light, ethylene and auxin signaling interaction regulates carotenoid biosynthesis during tomato fruit ripening. Frontiers in Plant Science 9, 1370.

Eum HL, Kim HB, Choi SB, Lee SK. 2009. Regulation of ethylene biosynthesis by nitric oxide in tomato (Solanum lycopersicum L.) fruit harvested at different ripening stages. European Food Research and Technology 228, 331-338. 
Fan B, Shen L, Liu KL, Zhao DY, Yu MM, Sheng JP. 2008. Interaction between nitric oxide and hydrogen peroxide in postharvest tomato resistance response to Rhizopus nigricans. Journal of the Science of Food and Agriculture 88, 1238-1244.

Freschi L. 2013. Nitric oxide and phytohormone interactions: current status and perspectives. Frontiers in Plant Science 4, 398.

Geisler AC, Rudolph TK. 2012. Nitroalkylation - a redox sensitive signaling pathway. Biochimica Biophysica Acta. 1820, 777-784.

Gémes K, Poór P, Horváth E, Kolbert Z, Szopkó D, Szepesi Á, Tari I. 2011. Crosstalk between salicylic acid and $\mathrm{NaCl}$-generated reactive oxygen species and nitric oxide in tomato during acclimation to high salinity. Physiologia Plantarum 142, 179-192.

Gergoff GEG, Alegre ML, Senn ME, Chaves AR, Simontacchi M, Bartoli CG. 2017. Combination of nitric oxide and 1-MCP on postharvest life of the blueberry (Vaccinium spp.) fruit. Postharvest Biology and Technology 33, 72-80.

Ghorbani B, Pakkish Z, Khezri M. 2018. Nitric oxide increases antioxidant enzyme activity and reduces chilling injury in orange fruit during storage. New Zealand Journal of Crop and Horticultural Science 46, 101-116.

Giovannoni JJ. 2004. Genetic regulation of fruit development and ripening. Plant Cell 16, S170-S180.

Giovannoni J, Nguyen C, Ampofo B, Zhong S, Fei Z. 2017. The epigenome and transcriptional dynamics of fruit ripening. Annual Review of Plant Biology 68, 61-84.

González-Gordo S, Bautista R, Claros MG, Cañas A, Palma JM, Corpas FJ. 2019. Nitric oxide-dependent regulation of sweet pepper fruit ripening. Journal of Experimental Botany, pii: erz136.

Goulao LF, Oliveira CM. 2008. Cell wall modifications during fruit ripening: when a fruit is not the fruit. Trends in Food Science and Technology 19, 4-25.

Gramegna G, Rosado D, Sánchez Carranza AP, Cruz AB, Simon-Moya M, Llorente B, Rodríguez-Concepción M, Freschi L, Rossi M. 2019. PHYTOCHROME-INTERACTING FACTOR 3 mediates light-dependent induction of tocopherol biosynthesis during tomato fruit ripening. Plant Cell Environment 42, 13281339.

Gu RX, Zhu SH, Zhou J, Liu N, Shi JY. 2014. Inhibition on brown rot disease and induction of defence response in harvested peach fruit by nitricoxide solution. European Journal of Plant Pathology 139, 363-372.

Guo Q, Wu B, Chen W, Zhang Y, Wang J, Li X. 2014. Effects of nitric oxide treatment on the cell wall softening related enzymes and several hormones of papaya fruit during storage. Food Science and Technology International 20, 309-317. 
Han S, Cai HF, An XJ, Huan C, Wu XQ, Jiang L, Yu ML, Ma RJ, Yu ZF. 2018. Effect of nitric oxide on sugar metabolism in peach fruit (cv. Xiahui 6) during cold storage. Postharvest Biology and Technology 142, 72-80.

Hong K, Gong D, Xu H, Wang S, Jia Z, Chen J, Zhang L. 2014. Effects of salicylic acid and nitric oxide pretreatment on the expression of genes involved in the ethylene signalling pathway and the quality of postharvest mango fruit. New Zealand Journal of Crop and Horticultural Science 42, 205-216.

Hu M, Yang D, Huber DJ, Jiang Y, Li M, Gao Z, Zhang Z. 2014. Reduction of postharvest anthracnose and enhancement of disease resistance in ripening mango fruit by nitric oxide treatment. Postharvest Biology and Technology 97, 115-122.

Hu MJ, Zhu YY, Liu GS, Gao ZY, Li M, Su ZH, Zhang ZK. 2019. Inhibition on anthracnose and induction of defense response by nitric oxide in pitaya fruit. Scientia Horticulturae 245, 224-230.

Huan C, Jiang L, An X, Yu M, Xu Y, Ma R, Yu Z. 2016. Potential role of reactive oxygen species and antioxidant genes in the regulation of peach fruit development and ripening. Plant Physiology and Biochemistry 104, 294-303.

Hung KT, Kao CH. 2003. Nitric oxide counteracts the senescence of rice leaves induced by abscisic acid. Journal of Plant Physiology 160, 871-879.

Huo J, Huang DJ, Zhang J, Fang H, Wang B, Wang CL, Liao WB. 2018. Hydrogen sulfide: a gaseous molecule in postharvest freshness. Frontiers in Plant Science 9, 1172.

Jiménez-Quesada MJ, Carmona R, Lima-Cabello E, Traverso JÁ, Castro AJ, Claros MG, Alché JD. 2017. Generation of nitric oxide by olive (Olea europaea L.) pollen during in vitro germination and assessment of the $S$-nitroso- and nitro-proteomes by computational predictive methods. Nitric Oxide 68, 23-37.

Kang R, Zhang L, Jiang L, Yu M, Ma R, Yu Z. 2016, Effect of postharvest nitric oxide treatment on the proteome of peach fruit during ripening. Postharvest Biology and Technology 112, 277-289

Karasawa MMG, Mohan C. 2018. Fruits as prospective reserves of bioactive compounds: a review. Natural Products and Bioprospecting 8, 335-346.

Karlova R, Chapman N, David K, Angenent GC, Seymour GB, de Maagd RA. 2014. Transcriptional control of fleshy fruit development and ripening. Journal of Experimental Botany 65, 4527-4541.

Kourmpetli S, Drea S. 2014. The fruit, the whole fruit, and everything about the fruit. Journal Experimental Botany 65, 4491-4503.

Kumar R, Khurana A, Sharma AK. 2014. Role of plant hormones and their interplay in development and ripening of fleshy fruits. Journal of Experimental Botany 65, 45614575 . 
Lai TF, Wang YY, Li BQ, Qin GZ, Tian SP. 2011. Defense responses of tomato fruit to exogenous nitric oxide during postharvest storage. Postharvest Biology and Technology 62, 127-132.

Leshem YY. 2000. Nitric oxide in plants: Occurrence, function and use. Dordrecht: Kluwer Academic Publishers.

Leshem YY, Pinchasov Y. 2000. Non-invasive photoacoustic spectroscopic determination of relative endogenous nitric oxide and ethylene content stoichiometry during the ripening of strawberries Fragaria anannasa (Duch.) and avocados Persea americana (Mill.). Journal Experimental Botany 51, 1471-1473.

Leshem YY, Wills RBH, Veng-Va Ku V. 1998. Evidence for the function of the free radical gas nitric oxide (NO) as an endogenous maturation and senescence regulating factor in higher plants. Plant Physiology and Biochemistry 36, 825-833

Li G, Zhu S, Wu W, Zhang C, Peng Y, Wang Q, Shi J. 2017. Exogenous nitric oxide induces disease resistance against Monilinia fructicola through activating the phenylpropanoid pathway in peach fruit. Journal of the Science of Food and Agriculture 97, 3030-3038.

Liang LJ, Deng YM, Sun XB, Jia XP, Su JL. 2018. Exogenous nitric oxide pretreatment enhances chilling tolerance of Anthurium. Journal of the American Society for Horticultural Science 143, 3-13.

Lindermayr C, Saalbach G, Bahnweg G, Durner J. 2006. Differential inhibition of Arabidopsis methionine adenosyltransferases by protein S-nitrosylation. Journal of Biological Chemistry 281, 4285-4291.

Liu M, Pirrello J, Chervin C, Roustan JP, Bouzayen M. 2015. Ethylene control of fruit ripening: revisiting the complex network of transcriptional regulation. Plant Physiology 169, 2380-2390.

Liu YF, Yang XX, Zhu SJ, Wang YQ. 2016. Postharvest application of MeJA and NO reduced chilling injury in cucumber (Cucumis sativus) through inhibition of $\mathrm{H}_{2} \mathrm{O}_{2}$ accumulation. Postharvest Biology and Technology 119, 77-83.

Liu J, Yang J, Zhang H, Cong L, Zhai R, Yang C, Wang Z, Ma F, Xu L. 2019. Melatonin inhibits ethylene synthesis via nitric oxide regulation to delay postharvest senescence in pears. Journal of Agricultural and Food Chemistry, doi: 10.1021/acs.jafc.8b06580.

Manjunatha G, Lokesh $\quad$ V, Neelwarne $\quad$ B, Singh $\quad$ Z, Gupta $\quad$ KJ. 2014 . Nitric oxide applications for quality enhancement of horticulture produce. Horticultural Reviews 42, 121-155.

Mata-Pérez C, Begara-Morales JC, Luque F, Padilla MN, Jiménez-Ruiz J, Sánchez-Calvo B, Fierro-Risco J, Barroso JB. 2016. transcriptomic analyses on the role of nitric oxide in plant disease resistance. Current Issues in Molecular Biology 19, 121-128. 
Mata-Pérez C, Sánchez-Calvo B,Padilla MN, Begara-Morales JC, Valderrama R, Corpas FJ, Barroso. 2017. Nitro-fatty acids in plant signaling: New key mediators of nitric oxide metabolism. Redox Biology 11, 554-561.

Mateos RM, León AM, Sandalio LM, Gómez M, del Río LA, Palma JM. 2003. Peroxisomes from pepper fruits (Capsicum annuиm L): Purification, characterization and antioxidant activity. Journal of Plant Physiology 160, 1507-1516.

Mateos RM, Bonilla-Valverde D, del Río LA, Palma JM, Corpas FJ. 2009. NADPdehydrogenases from pepper fruits: effect of maturation. Physiologia Plantarum 135, 130-139.

Melo NKG, Bianchetti RE, Lira BS, Oliveira PMR, Zuccarelli R, Dias DLO, Demarco D, Peres LEP, Rossi M, Freschi L. 2016. Nitric oxide, ethylene, and auxin crosstalk mediates greening and plastid development in deetiolating tomato seedlings, Plant Physiology 170, 2278-2294.

Mohamed MAAT, Abd El-khalek AF, Elmehrat HG, Mahmoud GA. 2016. Nitric oxide, oxalic acid and hydrogen peroxide treatments to reduce decay and maintain postharvest quality of 'Valencia' Orange fruits during cold storage. Egyptian Journal of Horticulture 43, 137-161.

Mukherjee S. 2019. Recent advancements in the mechanism of nitric oxide signaling associated with hydrogen sulfide and melatonin crosstalk during ethylene-induced fruit ripening in plants. Nitric Oxide 82, 25-34.

Muñoz-Vargas MA, González-Gordo S, Cañas A, López-Jaramillo J, Palma JM, Corpas FJ. 2018. Endogenous hydrogen sulfide $\left(\mathrm{H}_{2} \mathrm{~S}\right)$ is up-regulated during sweet pepper (Capsicum annuum L.) fruit ripening. In vitro analysis shows that NADPdependent isocitrate dehydrogenase (ICDH) activity is inhibited by $\mathrm{H}_{2} \mathrm{~S}$ and NO. Nitric Oxide 81, 36-45.

Muñoz-Vargas MA, González-Gordo S, Palma JM, Corpas FJ. 2019. Inhibition of NADP-malic enzyme activity by $\mathrm{H}_{2} \mathrm{~S}$ and $\mathrm{NO}$ in sweet pepper (Capsicum annuиm L.) fruits. Physiologia Plantarum, doi: 10.1111/ppl.13000.

Palma JM, Corpas FJ, del Río LA. 2011. Proteomics as an approach to the understanding of the molecular physiology of fruit development and ripening. Journal of Proteomics 74, 1230-1243

Palma JM, Sevilla F, Jiménez A, del Río LA, Corpas FJ, Álvarez de Morales P, Camejo DM. 2015. Physiology of pepper fruits and the metabolism of antioxidants: chloroplasts, mitochondria and peroxisomes. Annals of Botany 116, 627-636.

Palma JM, Álvarez de Morales P, del Río LA, Corpas FJ. 2018a. The proteome of fruit peroxisomes: sweet pepper (Capsicum annuum L.) as a model. Subcellular Biochemistry, Proteomics of Peroxisomes: Identifying Novel Functions and Regulatory Networks 89, 323-341.

Palma JM, Rodríguez-Ruiz M, González-Gordo S, Corpas FJ. 2018b. Interaction between antioxidants and reactive nitrogen species during pepper fruit ripening. Free Radical Biology and Medicine 120, S9. 
Palma JM, Gupta DK, Corpas FJ. 2019. Nitric oxide (NO) and hydrogen peroxide $\left(\mathrm{H}_{2} \mathrm{O}_{2}\right)$ generation in plant cells. Overview and queries. In: DK Gupta, JM Palma, FJ Corpas, eds. Nitric Oxide and Hydrogen Peroxide Signaling in Higher Plants. Springer, in press.

Patil AS, Maurer D, Feygenberg O, Alkan N. 2019. Exploring cold quarantine to mango fruit against fruit fly using artificial ripening. Science Reprts 9, 1948.

Peng J, Cao SF, Zheng YH. 2013. Managing chilling injury in fruits. Acta Horticulturae 1012, 1087-1095.

Piterkova J, Luhova L, Mieslerova B, Lebeda A, Petrivalsky M. 2013. Nitric oxide and reactive oxygen species regulate the accumulation of heat shock proteins in tomato leaves in response to heat shock and pathogen infection. Plant Science 207, 57-65.

Poór P, Kovács J, Borbély P, Takács Z, Szepesi Á, Tari I. 2015. Salt stress-induced production of reactive oxygen- and nitrogen species and cell death in the ethylene receptor mutant Never ripe and wild type tomato roots. Plant Physiology and Biochemistry 97, 313-322.

Prakash VP, Singh VP, Tripathi DK, Sharma S, Corpas FJ. 2019. Crosstalk between nitric oxide (NO) and abscisic acid (ABA) signalling molecules in higher plants. Environmental and Experimental Botany 161, 41-49.

Pristijono P, Wills RBH, Golding JB. 2008. Use of the nitric oxide donor compound, diethylenetriamine-nitric oxide (DETANO), as an inhibitor of browning in apple slices. Journal of Horticultural Science and Biotechnology 83, 555-558.

Prochazkova D, Wilhelmova N. 2011. Nitric oxide, reactive nitrogen species and associated enzymes during plant senescence. Nitric Oxide: Biology and Chemistry 24, $61-65$.

Rabiei V, Kakavand F, Zaare-Nahandi F, Razavi F, Aghdam MS. 2019. Nitric oxide and gamma-aminobutyric acid treatments delay senescence of cornelian cherry fruitsduring postharvest cold storage by enhancing antioxidant system activity. Scientia Horticulturae 243, 268-273.

Ranjbari F, Moradinezhad F, Khayyat M. 2018. Effect of nitric oxide and film wrapping on quality maintenance and alleviation of chilling injury on pomegranate fruit. Journal of Agricultural Science and Technology 20, 1025-1036.

Ren YF, He JY, Liu HY, Liu GQ, Ren XL. 2017. Nitric oxide alleviates deterioration and preserves antioxidant properties in 'Tainong' mango fruit during ripening. Horticulture Environment and Biotechnology 58, 27-37.

Rodrigues MA, Bianchetti RE, Freschi L. 2014. Shedding light on ethylene metabolism in higher plants. Frontiers in Plant Science 5, 665.

Rodríguez-Ruiz M, Mateos RM, Codesido V, Corpas FJ, Palma JM. 2017a. Characterization of the galactono-1,4-lactone dehydrogenase from pepper fruits and its modulation in the ascorbate biosynthesis. Role of nitric oxide. Redox Biology 12, 171181. 
Rodríguez-Ruiz M, Mioto P, Palma JM, Corpas FJ. 2017b. S-nitrosoglutathione reductase (GSNOR) activity is down-regulated during pepper (Capsicum annuum L.) fruit ripening. Nitric Oxide - Biology and Chemistry 68, 51-55.

Romero-Puertas MC, Delledonne M. 2003. Nitric oxide signaling in plant-pathogen interactions. IUBMB Life 55, 579-583.

Ruan J, Li M, Jin H, Sun L, Zhu Y, Xu M, Dong J. 2015. UV-B irradiation alleviates the deterioration of cold-stored mangoes by enhancing endogenous nitric oxide levels. Food Chemistry 169, 417-423.

Rudell DR, Mattheis JP. 2006. Nitric oxide and nitrite treatments reduce ethylene evolution from apple fruit disks. HortScience 41, 1462-1465.

Saba MK, Moradi S. 2017. Sodium nitroprusside (SNP) spray to maintain fruit quality and alleviate postharvest chilling injury of peach fruit. Scientia Horticulturae 216, 193199.

Sánchez-Calvo B, Barroso JB, Corpas FJ. 2013. Hypothesis: Nitro-fatty acids play a role in plant metabolism. Plant Science 199-200, 1-6.

Shi JY, Li JX, Zhu SH, Zhou J. 2011. Browning inhibition on fresh-cut chestnut kernel by exogenous nitric oxide. International Journal of Food Science and Technology 46, 944-950.

Shi JY, Liu N, Gu RX, Zhu LQ, Zhang C, Wang QG, Lei ZH, Liu YY, Ren JY. 2015. Signals induced by exogenous nitric oxide and their role in controlling brown rot disease caused by Monilinia fructicola in postharvest peach fruit. Journal of General Plant Pathology 81, 68-76.

Singh SP, Singh Z, Swinny EE. 2009. Postharvest nitric oxide fumigation delays fruit ripening and alleviates chilling injury during cold storage of Japanese plums (Prunus salicina Lindell). Postharvest Biology and Technology 53, 101-108.

Steelheart C, Galatro A, Bartoli CG, Grozeff GEG. 2019. Nitric oxide and hydrogen peroxide: Signals in fruit ripening. In: DK Gupta, JM Palma, FJ Corpas, eds. Nitric Oxide and Hydrogen Peroxide Signaling in Higher Plants, pp. 175-199, Springer, Cham, Switzerland.

Su L, Diretto G, Purgatto E, Danoun S, Zouine M, Li Z, Roustan J-P, Bouzayen M, Giuliano G, Chervin C. 2015. Carotenoid accumulation during tomato fruit ripening is modulated by the auxin-ethylene balance. BMC Plant Biology 15, 1-12.

Suzuki N, Miller G, Morales J, Shulaev V, Torres MA, Mittler R. 2011. Respiratory burst oxidases: the engines of ROS signaling. Current Opinion in Plant Biology 14, 691699.

Tanou G, Minas IS, Karagiannis E, Tsikou D, Audebert S, Papadopoulou KK, Molassiotis A. 2015. The impact of sodium nitroprusside and ozone in kiwifruit ripening physiology: a combined gene and protein expression profiling approach. Annals of Botany 116, 649-662. 
Tareen M, Singh Z, Khan AS, Abbasi NA, Naveed M. 2017. Combined applications of aminoethoxyvinylglycine with salicylic acid or nitric oxide reduce oxidative stress in peach during ripening and cold storage. Journal of Plant Growth Regulation 36, 983994.

Tohge T, Alseekh S, Fernie AR. 2014. On the regulation and function of secondary metabolism during fruit development and ripening. Journal of Experimental Botany $\mathbf{6 5}$, 4599-4611.

Venkatachalam K. 2018. Exogenous nitric oxide treatment impacts antioxidant response and alleviates chilling injuries in longkong pericarp. Scientia Horticulturae 237, 311-317.

Wang YS, Luo Z, Khan Zu, Mao L, Ying T. 2015. Effect of nitric oxide on energy metabolism in postharvest banana fruit in response to chilling stress. Postharvest Biology and Technology 108, 21-27.

Wang YS, Luo ZS, Mao LC, Ying TJ. 2016. Contribution of polyamines metabolism and GABA shunt to chilling tolerance induced by nitric oxide in cold-stored banana fruit. Food Chemistry 197, 333-339.

Wang D, Li L, Xu YQ, Limwachiranon J, Li D, Ban ZJ, Luo ZS. 2017. Effect of exogenous nitro oxide on chilling tolerance, polyamine, proline, and gammaaminobutyric acid in bamboo shoots (Phyllostachys praecox $\mathrm{f}$. prevernalis). Journal of Agricultural and Food Chemistry 65, 5607-5613.

Wu F, Yang H, Chang Y, Cheng J, Bai S, Yin J. 2012. Effects of nitric oxide on reactive oxygen species and antioxidant capacity in Chinese Bayberry during storage. Scientia Horticulturae 135, 106-111.

Wu B, Guo Q, Li Q, Ha Y, Li X, Chena W. 2014. Impact of postharvest nitric oxide treatment on antioxidant enzymes and related genes in banana fruit in response to chilling tolerance. Postharvest Biology and Technology 92, 157-163.

Yang H, Wu F, Cheng J. 2011. Reduced chilling injury in cucumber by nitric oxide and the antioxidant response. Food Chemitry 127, 1237-1242.

Yu Q, Chen Q, Chen ZW, Xu HK, Fu MM, Li SC, Wang HZ, Xu MJ. 2012. Activating defense responses and reducing postharvest blue mold decay caused by Penicillium expansum in peach fruit by yeast saccharide. Postharvest Biology and Technology 74, 100-107.

Zaharah SS, Singh Z. 2011. Postharvest nitric oxide fumigation alleviates chilling injury, delays fruit ripening and maintains fruit quality in cold-storage "Kensington Pride" mango. Postharvest Biology and Technology 60, 202-210.

Zhang LL, Zhu SH, Chen CB, Zhou J. 2011. Metabolism of endogenous nitric oxide during growth and development of apple fruit. Scientia Horticulturae 127, 500-506. 
Zhang T, Che FB, Zhang H, Pan Y, Xu MQ, Ban QY, Han Y, Rao JP. 2017a. Effect of nitric oxide treatment on chilling injury, antioxidant enzymes and expression of the CmCBF1 and $\mathrm{CmCBF} 3$ genes in cold-stored Hami melon (Cucumis melo L.) fruit. Postharvest Biology and Technology 127, 88-98.

Zhang XH, Min DD, Li FJ, Ji NN, Meng DM, Li L. 2017b. Synergistic effects of 1arginine and methyl salicylate on alleviating postharvest disease caused by Botrysis cinerea in tomato fruit. Journal of Agricultural and Food Chemistry 65, 4890-4896.

Zhang Y, Li Y, He Y, Hu W, Zhang Y, Wang X, Tang H. 2018. Identification of NADPH oxidase family members associated with cold stress in strawberry. FEBS Open Bio 8, 593-605.

Zheng YY, Shen L, Yu MM, Fan B, Zhao DY, Liu LY, Sheng JP. 2011a. Nitric oxide synthase as a postharvest response in pathogen resistance of tomato fruit. Postharvest Biology and Technology 60, 38-46.

Zheng YY, Sheng JP, Zhao RR, Zhang J, Lv SN, Liu LY, Shen L. 2011b. Preharvest L-arginine treatment induced postharvest disease resistance to Botrysis cinerea in tomato fruits. Journal of Agricultural and Food Chemistry 59, 6543-6549.

Zheng YY, Hong H, Chen L, Li JY, Sheng JP, Shen L. 2014. LeMAPK1, LeMAPK2, and LeMAPK3 are associated with nitric oxide-induced defense response against Botrytis cinerea in the Lycopersicon esculentum fruit. Journal of Agricultural and Food Chemistry 62, 1390-1396.

Zheng YY, Yang Y, Liu C, Chen L, Sheng JP, Shen L. 2015. Inhibition of SIMPK1, SIMPK2, and SIMPK3 disrupts defense signaling pathways and enhances tomato fruit susceptibility to Botrytis cinerea. Journal of Agricultural and Food Chemistry 63, 5509-5517.

Zheng XL, Hu B, Song LJ, Pan J, Liu MM. 2017. Changes in quality and defense resistance of kiwifruit in response to nitric oxide treatment during storage at room temperature. Scientia Horticulturae 222, 187-192.

Zhou Y, Li S, Zeng K. 2016. Exogenous nitric oxide-induced postharvest disease resistance in citrus fruit to Colletotrichum gloeosporioides. Journal of the Science of Food and Agriculture 96, 505-512.

Zhu SH, Liu MC, Zhou J. 2006. Inhibition by nitric oxide of ethylene biosynthesis and lipoxygenase activity in peach fruit during storage. Postharvest Biology and Technology 42, 41-48.

Zhu S, Zhou J. 2007. Effect of nitric oxide on ethylene production in strawberry fruit during storage. Food Chemistry 100, 1517-1522.

Zhu S, Sun L, Zhou J. 2010. Effects of different nitric oxide application on quality of kiwifruit during $20^{\circ} \mathrm{C}$ storage. International Journal of Food Science \& Technology 45, 245-251. 
Ziogas V, Molassiotis A, Fotopoulos V, Tanou G. 2018. Hydrogen Sulfide: A Potent Tool in Postharvest Fruit Biology and Possible Mechanism of Action. Frontiers in Plant Science. 9, 1375.

\section{$542 \quad$ Figure legends}

543 Figure 1. Ethylene biosynthesis pathway and methionine recycling in plants. Ethylene 544 is synthesized in a two-step pathway which involves the enzymes ACC synthase and 545 ACC oxidase. The S-Adenosyl methionine (SAM) is continuously replaced by a 546 methionine cycle (Yang cycle), although SAM can also be derived to the biosynthesis 547 of the polyamines spermidine and spermine. Nitric oxide (NO) inhibits the ACC 548 synthase and ACC oxidase activity, and it also affects the SAM synthetase, also known 549 as methionine adenosyltransferases (MAT), by a $S$-nitrosation event. On the other hand, 550 melatonin can stimulate the biosynthesis of NO. ACC, 1-aminocyclopropane-1551 carboxylic acid; MTA, 5-methylthioadenosine; MTR, 5-methylthioribose; KMB, 2552 keto-4-methylthiobutyrate.

553 Figure 2. Metabolism of NO in fruits. The levels of internal NO can be modified by 554 either (A) subjecting fruits to high exogenous NO levels, or (B) stimulating the 555 endogenous NO production by the use of L-arginine, methyl salicylate (MeSa), the 556 elicitor of Botrytis cinerea (B.c.) or yeast saccharide (YS). (C) NO, which is in a higher 557 concentration in immature green fruits than in red ripe, can be driven to protein Tyr558 nitration and $S$-nitrosation processes which are increased at ripening. Besides, nitro559 alkylation of proteins mediated by fatty acids (FA) may occur as reported elsewhere. In 560 either green or red fruits, NO can also participate in signaling trials. 
Table 1. Effects of NO treatment on physiological traits and interactions between NO and the oxidative metabolism in some climacteric and non-climacteric fruits

\begin{tabular}{|c|c|c|c|c|}
\hline Fruit & NO donor & Effects & $\begin{array}{c}\text { Main interactions with oxidative metabolism } \\
\text { (ROS and antioxidants) }\end{array}$ & Reference \\
\hline \multicolumn{5}{|l|}{ Climacteric } \\
\hline $\begin{array}{l}\text { Apple } \\
\text { (Malus domestica) }\end{array}$ & DETANO & $\begin{array}{l}\text { - Inhibition of browning in apple } \\
\text { slices } \\
\text { - Increases postharvest life }\end{array}$ & - & Pristijono et al., 2008 \\
\hline $\begin{array}{l}\text { Banana } \\
\text { (Musa spp.) }\end{array}$ & SNP & $\begin{array}{l}\text { - Enhances chilling tolerance } \\
\text { - Lowers ethylene production and } \\
\text { malondialdehyde content }\end{array}$ & $\begin{array}{l}\text { - Lowers } \mathrm{O}_{2} \text { production and hydrogen peroxide }\left(\mathrm{H}_{2} \mathrm{O}_{2}\right) \\
\text { content } \\
\text { - Increases activities of SOD, CAT, APX and POD }\end{array}$ & $\begin{array}{l}\text { Cheng et al., } 2009 \\
\text { Wu } \text { et al., } 2014 \\
\text { Wang } \text { et al., } 2015\end{array}$ \\
\hline $\begin{array}{l}\text { Hami melon (Cucumis } \\
\text { melo) }\end{array}$ & NO gas & $\begin{array}{l}\text { - Decreases chilling injury and } \\
\text { incidence }\end{array}$ & $\begin{array}{l}\text { - Decreases the rates of } \mathrm{O}_{2} \text { and } \mathrm{H}_{2} \mathrm{O}_{2} \text { contents } \\
\text { - Increases activity of SOD, CAT, POD and APX }\end{array}$ & Zhang et al., 2017a \\
\hline $\begin{array}{l}\text { Highbush blueberry } \\
\text { (Vaccinium corymbosum) }\end{array}$ & GSNO & $\begin{array}{l}\text { - Increases firmness and } \\
\text { postharvest life } \\
\text { - Alleviates weight loss }\end{array}$ & - Increases ascorbate and glutathione contents & Gergoff et al., 2017 \\
\hline $\begin{array}{l}\text { Japanese plum fruit } \\
\text { (Prunus salicina) }\end{array}$ & NO gas & $\begin{array}{l}\text { - Delays ripening } \\
\text { - Alleviates chilling injury } \\
\text { symptoms during cold storage }\end{array}$ & - & Singh et al., 2009 \\
\hline $\begin{array}{l}\text { Kiwi } \\
\text { (Actinidia chinensis) }\end{array}$ & NO gas/solution & $\begin{array}{l}\text { - Extend postharvest life } \\
\text { - Decreases ethylene production }\end{array}$ & $\begin{array}{l}\text { - Promotes higher ascorbate content } \\
\text { - Increases antioxidant activity } \\
\text { - Lowers lipid peroxidation }\end{array}$ & Zhu et al., 2010 \\
\hline $\begin{array}{l}\text { Longkong (Lansium } \\
\text { domesticum) }\end{array}$ & SNP & $\begin{array}{l}\text { - Enhances chilling tolerance and } \\
\text { reduces eletrolyte leakage }\end{array}$ & $\begin{array}{l}\text { - Regulate the rates of } \mathrm{O}_{2}-\text { and } \mathrm{H}_{2} \mathrm{O}_{2} \text { contents } \\
\text { - Increases activity of SOD, CAT, POD and APX }\end{array}$ & Venkatachalam 2018 \\
\hline $\begin{array}{l}\text { Mango } \\
\text { (Mangifera indica) }\end{array}$ & SNP & $\begin{array}{l}\text { - Increases fruit firmness } \\
\text { - Alleviates cold damage and } \\
\text { chilling injury } \\
\text { - Lowers respiration peak and } \\
\text { softening } \\
\text { - Delays fruit color development } \\
\text { and ripening } \\
\text { - Increases disease resistance } \\
\text { - Reduces the respiration rate and } \\
\text { electrolyte leakage }\end{array}$ & $\begin{array}{l}\text { - Increases activities of SOD, CAT, and POD } \\
\text { - Lowers } \mathrm{O}_{2}^{--} \text {production and } \mathrm{H}_{2} \mathrm{O}_{2} \text { content } \\
\text { - Increases activity of LP and PPO }\end{array}$ & $\begin{array}{c}\text { Zaharah and Sing, } \\
2011 \\
\text { Barman et al., } 2014 \\
\text { Hu et al., } 2014 \\
\text { Ruan et al., } 2015 \\
\text { Ren } \text { et al., } 2017\end{array}$ \\
\hline
\end{tabular}




\begin{tabular}{|c|c|c|c|c|}
\hline $\begin{array}{l}\text { Papaya } \\
\text { (Carica papaya) }\end{array}$ & NO gas & $\begin{array}{l}\text { - Delays ripening and lowers } \\
\text { softening } \\
\text { - Lowers ethylene production, } \\
\text { auxins, and abscisic acid content }\end{array}$ & $\begin{array}{l}\text { - Maintains high antioxidant capacity and total phenol and } \\
\text { ascobate contents }\end{array}$ & $\begin{array}{l}\text { Guo et al., } 2014 \\
\text { Lata et al., } 2018\end{array}$ \\
\hline $\begin{array}{l}\text { Peach } \\
\text { (Prunus persica) }\end{array}$ & NO gas & $\begin{array}{l}\text { - Delays fruit senescence } \\
\text { - Increases firmness } \\
\text { - Increases resistance to } \\
\text { environmental stress and disease } \\
\text { - Lowers ethylene production } \\
\end{array}$ & $\begin{array}{l}\text { - Increases levels of SOD and the enzymes of the ascorbate- } \\
\text { glutathione cycle } \\
\text { - Increases contents of phenolics and flavonoids }\end{array}$ & $\begin{array}{l}\text { Kang et al., } 2016 \\
\text { Li et al., } 2017 \\
\text { Han } \text { et al., } 2018\end{array}$ \\
\hline $\begin{array}{l}\text { Peach } \\
(P . \text { persica })\end{array}$ & SNP & - Maintains firmness & $\begin{array}{l}\text { - Promotes accumulation of reactive oxygen species } \\
\text { - Decreases the activity of SOD, CAT and POD }\end{array}$ & $\begin{array}{l}\text { Saba et al., } 2017 \\
\text { Tareen } \text { et al., } 2017\end{array}$ \\
\hline $\begin{array}{l}\text { Tomato } \\
\text { (Solanum lycopersicum) }\end{array}$ & NO/SNP & $\begin{array}{l}\text { - Suppresses growth } \\
\text { - Delays ripening } \\
\text { - Increases firmness } \\
\text { - Improves resistance to } \\
\text { pathogenic fungi }\end{array}$ & - Increases activity of SOD, CAT, POD, GST and PPO & $\begin{array}{l}\text { Eum et al., } 2009 \\
\text { Lai et al., } 2011 \\
\text { Bodanapu et al., } 2016\end{array}$ \\
\hline \multicolumn{5}{|l|}{ Non-Climacteric } \\
\hline $\begin{array}{l}\text { Chinese bayberry } \\
\text { (Myrica rubra) }\end{array}$ & NO gas & $\begin{array}{l}\text { - Affects firmness } \\
\text { - Lowers ethylene production } \\
\text { - Improves disease resistance }\end{array}$ & $\begin{array}{l}\text { - Decreases total phenolics contents and DPPH radical- } \\
\text { scavenging activity } \\
\text { - Delays the rates of } \mathrm{O}_{2}^{--} \text {and } \mathrm{H}_{2} \mathrm{O}_{2} \text { contents } \\
\text { - Lowers lipid peroxidation } \\
\text { - Increases activities of SOD, CAT and APX }\end{array}$ & Wu et al., 2012 \\
\hline $\begin{array}{l}\text { Cucumber } \\
\text { (Cucumis sativus) }\end{array}$ & NO gas & $\begin{array}{l}\text { - Extends postharvest life } \\
\text { - Improves chilling tolerance }\end{array}$ & $\begin{array}{l}\text { - Lowers } \mathrm{O}_{2}^{--} \text {and } \mathrm{H}_{2} \mathrm{O}_{2} \text { levels } \\
\text { - Lowers lipid peroxidation } \\
\text { - Increases activities of SOD, CAT, APX and POD }\end{array}$ & $\begin{array}{l}\text { Leshem et al., } 1998 \\
\text { Yang } \text { et al., } 2011\end{array}$ \\
\hline $\begin{array}{l}\text { Orange } \\
\text { (Citrus sinensis) }\end{array}$ & SNP & $\begin{array}{l}\text { - Lowers weight loss } \\
\text { - Improves resistance to fungi } \\
\text { - Decreases chilling injury and } \\
\text { incidence }\end{array}$ & $\begin{array}{l}\text { - Lowers } \mathrm{H}_{2} \mathrm{O}_{2} \text { content } \\
\text { - Increases ascorbate and phenolics contents } \\
\text { - Increases activity of CAT, ascorbate-glutathione cycle } \\
\text { enzymes, POD and PPO }\end{array}$ & $\begin{array}{l}\text { Mohamed et al., } 2016 \\
\text { Zhou } \text { et al., } 2016 \\
\text { Ghorbani et al., } 2018\end{array}$ \\
\hline $\begin{array}{l}\text { Strawberry } \\
\text { (Fragaria anannasa) }\end{array}$ & $\begin{array}{c}\text { NO } \\
\text { gas/DETANO/SNP }\end{array}$ & $\begin{array}{l}\text { - Extends postharvest life } \\
\text { - Lowers ethylene production and } \\
\text { respiration rate }\end{array}$ & - & $\begin{array}{c}\text { Leshem and } \\
\text { Pinchasov, } 2000 \\
\text { Wills et al., 2000, } \\
2007 \\
\text { Zhu and Zhou, } 2007\end{array}$ \\
\hline $\begin{array}{l}\text { Sweet pepper } \\
\text { (Capsicum annuum) }\end{array}$ & NO gas & - Delays fruit ripening & $\begin{array}{l}\text { - Increases ascorbate and glutathione contents and APX } \\
\text { activity }\end{array}$ & $\begin{array}{l}\text { Chaki et al., } 2015 \\
\text { González-Gordo et }\end{array}$ \\
\hline
\end{tabular}




\begin{tabular}{|l|l|l|l|l|}
\hline & & & $\begin{array}{l}\text { - Enhances gene expression and enzyme activity of GalLDH } \\
\text { - Lowers protein nitration }\end{array}$ & al., 2019 \\
\hline
\end{tabular}

APX, ascorbate peroxidase; CAT, catalase; DETANO, Diethylenetriamine-nitric oxide; DPPH, 2,2-diphenyl-1-picrylhydrazyl; GalLDH, L-galactono-1,4-lactone

dehydrogenase; GSNO, nitrosoglutathione; GST, glutathione-S-transferase; LP, lipoxygense; POD, peroxidase; PPO, polyphenol oxidase; SNP, sodium nitroprusside; SOD, superoxide dismutase. 
Table 2. Interaction of NO and the defense responses of some fruits

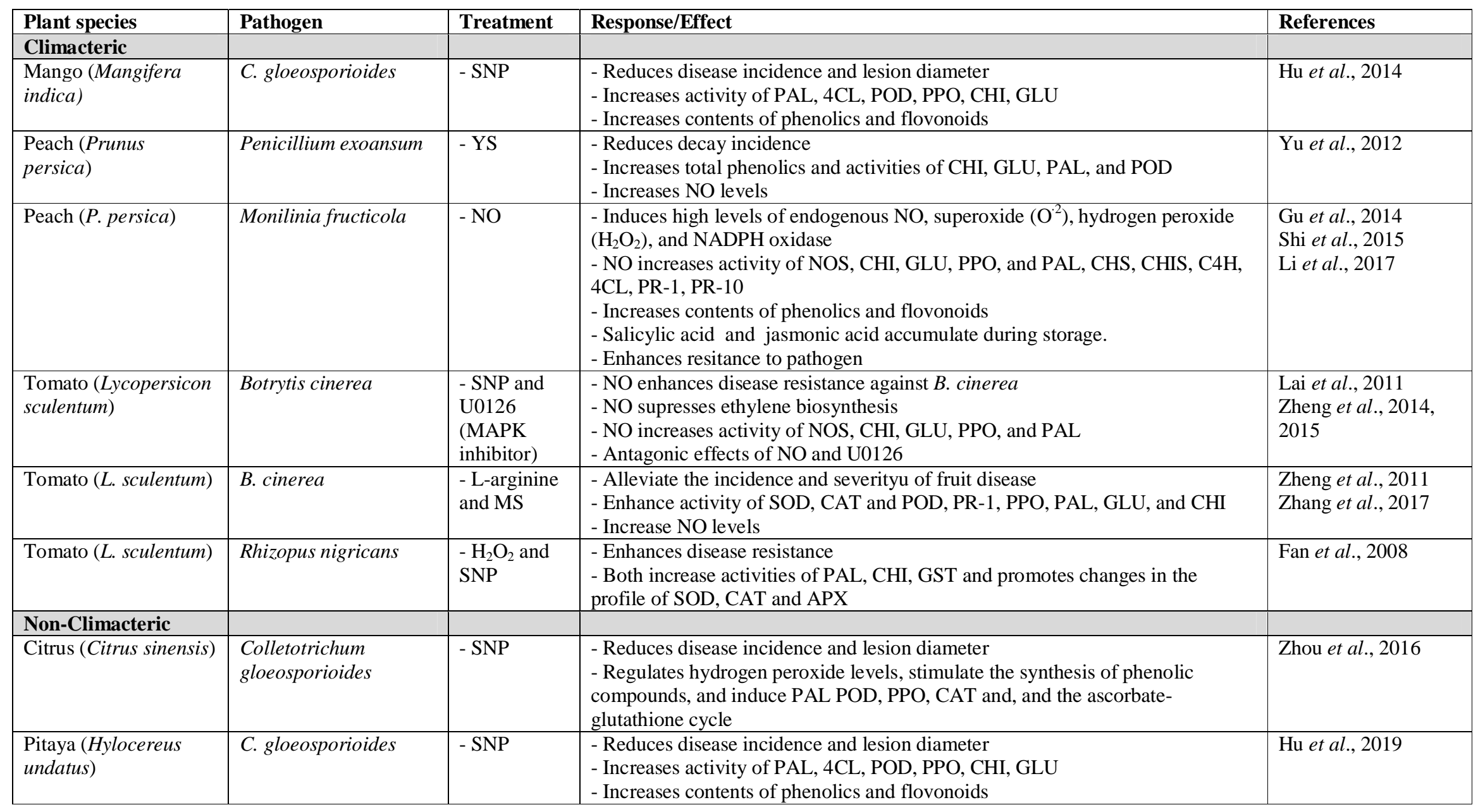


APX, ascorbate peroxidase; CAT, catalase; 4CH, cinnamate-4-hydroxylase; $\mathrm{CHI}$, chitinase; CHIS, chalcone isomerase CHS, chalcone synthase; 4CL, 4-coumaroyl-CoA ligase; GLU, beta-1,3-glucanases; MAPK, mitogen-activated protein kinases; MS, methyl salicylate; POD, peroxidase; PPO, polyphenol oxidase; PR-1, PR-10, pathogenesisrelated proteins 1 and 10; SNP, sodium nitroprusside; SOD, superoxide dismutase; U0126 (1,4-diamino-2,3-dicyano-1,4-bis( o - aminophenylmercapto)butadiene); YS, yeast saccharide. 


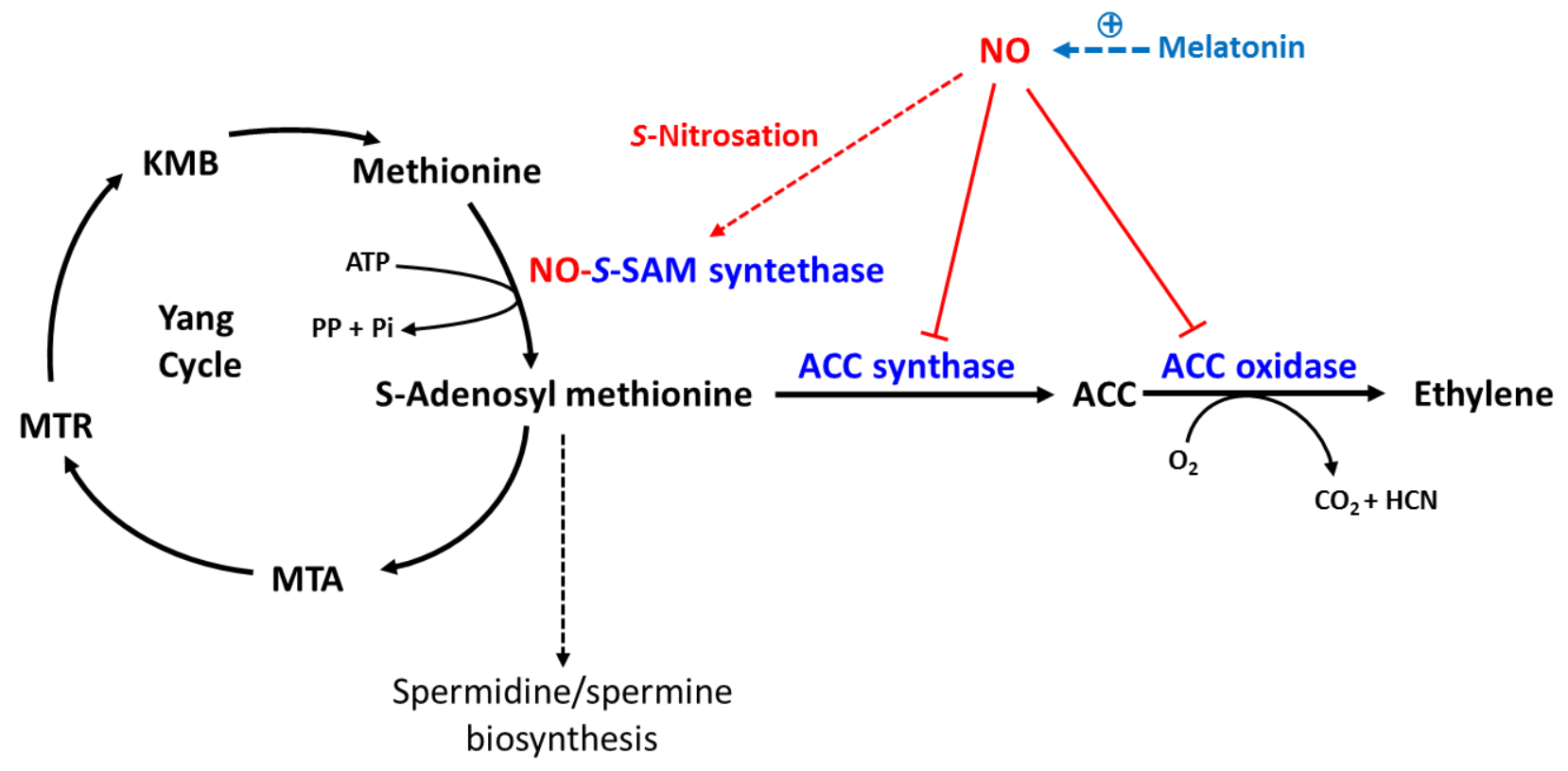

Figure 1. Ethylene biosynthesis pathway and methionine recycling in plants. Ethylene is synthesized in a two-step pathway which involves the enzymes ACC synthase and ACC oxidase. The S-Adenosyl methionine (SAM) is continuously replaced by a methionine cycle (Yang cycle), although SAM can also be derived to the biosynthesis of the polyamines spermidine and spermine. Nitric oxide (NO) inhibits the ACC synthase and ACC oxidase activity, and it also affects the SAM synthetase, also known as methionine adenosyltransferases (MAT), by a $S$ nitrosation event. On the other hand, melatonin can stimulate the biosynthesis of NO. ACC, 1aminocyclopropane-1-carboxylic acid; MTA, 5-methylthioadenosine; MTR, 5-methylthioribose; $\mathrm{KMB}$, 2-keto-4-methylthiobutyrate. 

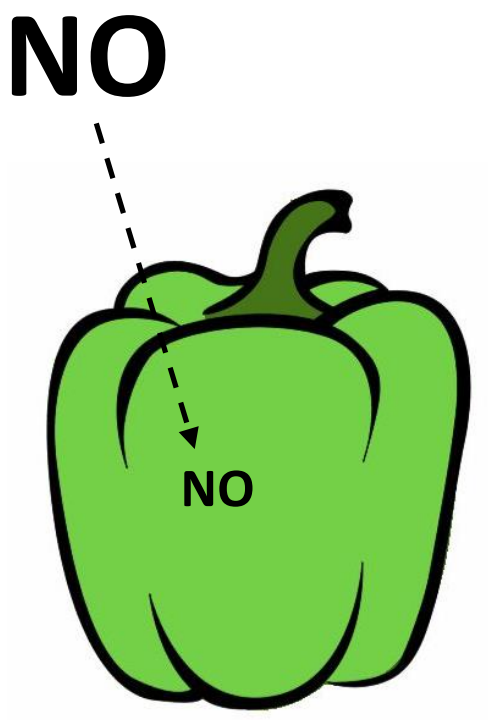

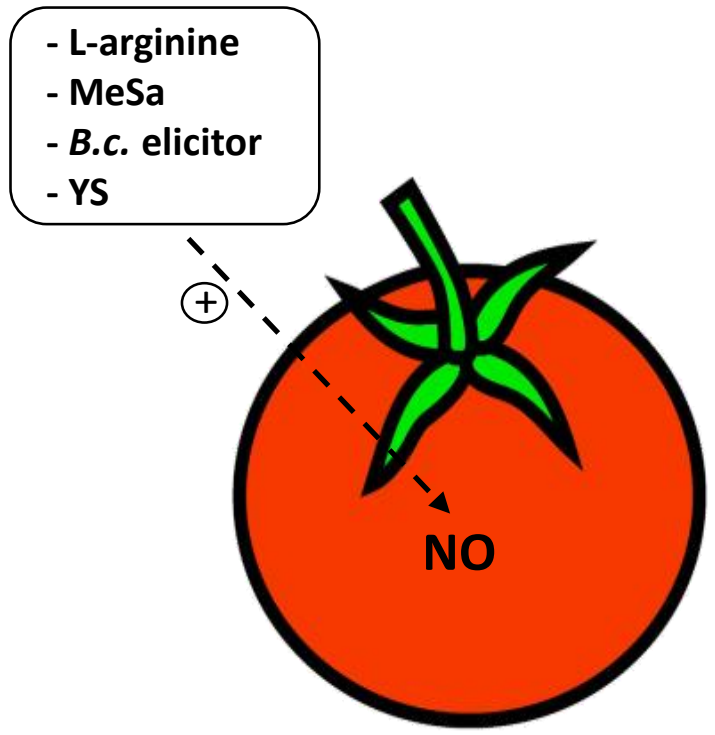

C

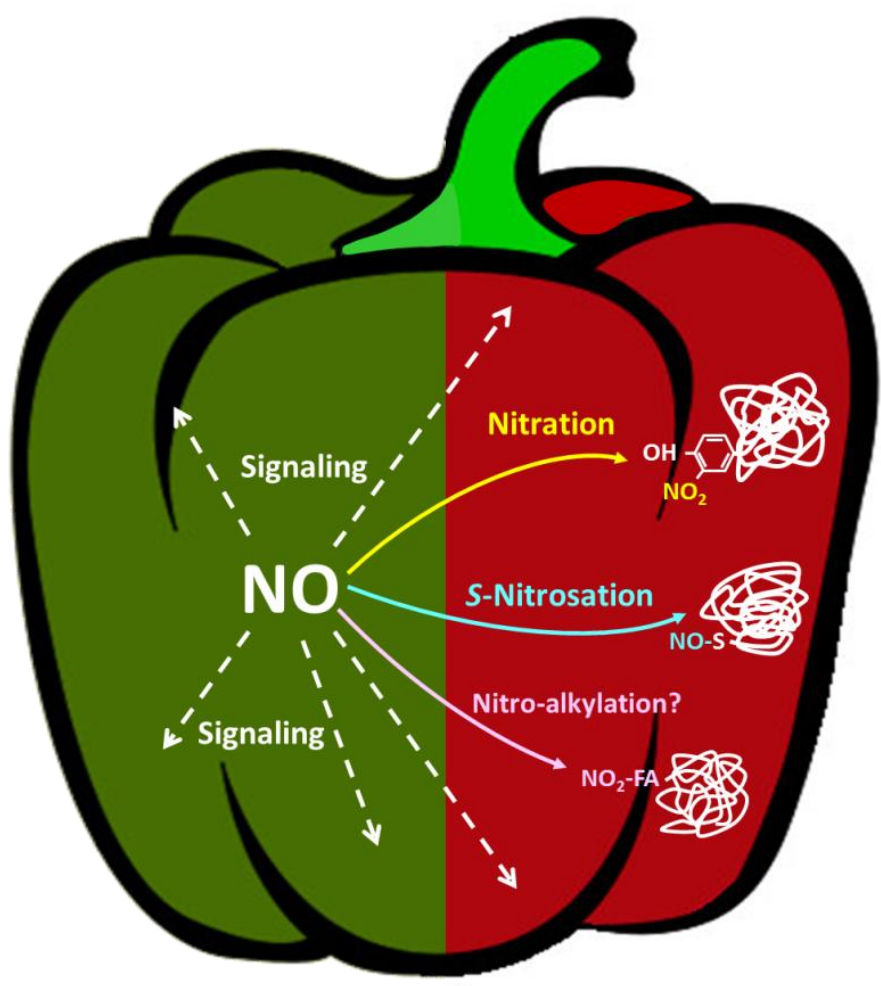

Figure 2. Metabolism of NO in fruits. The levels of internal NO can be modified by either (A) subjecting fruits to high exogenous NO levels, or (B) stimulating the endogenous NO production by the use of L-arginine, methyl salicylate (MeSa), the elicitor of Botrytis cinerea (B.c.) or yeast saccharide (YS). (C) NO, which is in a higher concentration in immature green fruits than in red ripe, can be driven to protein Tyr-nitration and $S$-nitrosation processes which are increased at ripening. Besides, nitro-alkylation of proteins mediated by fatty acids (FA) may occur as reported elsewhere. In either green or red fruits, NO can also participate in signaling trials. 